\title{
Relationship of Pay and Job Satisfaction
}

\author{
Martin Serreqi \\ Department of Management, Faculty of \\ Economy, University of Tirana
}

\section{Abstract}

The study measures the relationships of pay satisfaction and its dimensions (pay level, benefits, pay raises and administration/structure) with job satisfaction. A total of 200 public sector employees, from different companies and non-governmental, independent institutions participated. The results showed that overall pay satisfaction and pay level affected job satisfaction while pay raises, benefits and administration/structure did not. The results and limitations of the study were discussed and suggestions on future research were given.

Keywords: pay satisfaction, pay level, benefits, pay raise, administration, structure, job satisfaction

\section{Introduction}

Pay is an important aspect of doing business because it represents both, one of the largest organizational expenses, and one the most valued employee outcomes (Shaw, Duffy, Jenkins, \& Gupta, 1999). Pay includes several forms of compensation such as "direct, cash payments (for example, salary); indirect, noncash payments (for example, benefits); the amount of pay raises and the process by which the compensation system is administered" (Williams et al., 2006, p. 392). The importance of pay to most employees makes it necessary for companies to analyze the attitudes and behaviors of these employees towards pay, in order to establish the right policies and structures to perform more effectively. Pay satisfaction refers to the extent to which a person is satisfied with the process and level of direct or indirect monetary rewards received for work (Ducharme et al., 2005), or in other words, as the "amount of overall positive affect (or feelings) individuals have toward pay" (Miceli \& Lane, 1991, p.246).

Early researchers considered pay satisfaction an unidimensional construct (Orpen \& Bonnici, 1987) and used either ad hoc measures or the pay satisfaction sub-scales of both the Minnesota Satisfaction Questionnaire (MSQ) and the Job Descriptive Index (JDI) (Fong \& Shaffer, 2003). A major break-through in the research was made with the conceptualization of Pay Satisfaction Questionnaire by Heneman and Schwab 
(1985), as the first multi-dimensional construct of pay satisfaction. PSQ was a more appropriate measuring instrument than the Minnesota Satisfaction Questionnaire (MSQ) and Job Descriptive Index (JDI) because its values explained more areas of pay satisfaction (Judge, 1993; Scarpello et al.1988).

Nowadays, there is wide evidence to support the multidimensionality of pay satisfaction with the majority of studies showing that there are four dimensions (Carraher and Buckley, 1996; Currall et al., 2005; DeConinck et al., 1996; Heneman et al., 1988; Judge, 1993; Scarpello et al., 1988; Shaw et al., 1999), namely (1) pay level, (2) benefits, (3) pay raises, and (4) pay structure and administration. However most of the research on pay satisfaction has been focused on its dimensionality and antecedents. Vandenberghe and Tremblay (2008) advised on switching the focus of the research on to the consequences of pay satisfaction as a necessity to understand them better.

Job satisfaction is one of the most important consequences of pay satisfaction because it is related with other work outcomes (Hulin, 1991; Kinicki et al., 2002; Koh and Boo, 2001). Locke (1976) defined job satisfaction as "a pleasurable or positive emotional state, resulting from the appraisal of one's job experiences" ( $p$ 1304). It is a global concept comprised of various facets, which depending on the categorization can range from five (Smith, Kendall, \& Hulin, 1969) to nine (Locke, 1976; Westlund and Hannon, 2008). Out of all the different facets of job satisfaction, pay satisfaction requires independent assessment because of the big implications with organizational expenses (Currall, Towler, Judge, \& Kohn, 2005; Ram \& Prabhakar, 2010). There are several studies on the pay and job satisfaction relationship (Ago, Mueller and Price, 1993; Best and Thurston, 2006; Tremblay, Sire and Balkin, 2000), however most treat pay satisfaction as a unidimensional construct (Singh and Loncar, 2010).

The purpose of this paper is to explore the nature of the relationships of pay satisfaction and each of its dimensions with job satisfaction. The originality and value of the research is due to the use of a multidimensional factor, its focus on an outcome variable and its applications in a developing economy like Albania where there is very little- if any at all- research on pay satisfaction.

\section{Methods and Procedures}

200 questionnaires were collected via Google forms from public sector employees. Most of the respondents were females (54.5\%) and the rest were males (45.5\%). The majority of the employees sampled were under the age of 35 years (43.5\%), those in the $35-45$ years age group were $38.5 \%$, followed by the $45-55$ years group $(11 \%)$ with the rest being older than 55 years. The majority of the respondents $(60.5 \%)$ had less than 15 years of work experience and $62.5 \%$ had been less than 5 years at their current position. More than half of them (51.5\%) were non managerial employees with the rest being managers of all three levels. 
The data were collected using an Albanian version of the survey scales. The questionnaire with 33 questions divided in three sections was developed by utilizing previously used and very reliable measures. The first section with 10 questions was used to acquire information on the participants' demographics characteristics. The second section with 18 questions asked the participants to rate their pay satisfaction levels. The final section with the remaining 5 questions asked the employees about their job satisfaction. The levels of pay satisfaction were rated with a five point Likert Scale with 1 being "Very Dissatisfied" and 5 being "Very Satisfied" and the levels of job satisfaction were rated with a five point Likert scale with 1 being "Strongly Disagree" and 5 being "Strongly Agree".

Heneman and Schwab's (1985) four dimensional Pay Satisfaction Questionnaire, the most popular multifaceted measure of the construct, (Carraher and Buckley, 1996), (Vandenberghe and Tremblay, 2008) was used to measure pay satisfaction. The four scales measure satisfaction with pay level, benefits, pay raise and pay structure and administration. There were four questions on pay level (e.g. How satisfied are you with the size of your current salary? How satisfied are you with your overall level of pay?); four questions on benefits (e.g. How satisfied are you with your benefits package? How satisfied are you with the value of your benefits?); four questions on pay raise (e.g. How satisfied are you with the raises you have typically received in the past? How satisfied are you with your most recent raise?); and six questions on pay structure/ administration (e.g. How satisfied are you with the way the organization administers pay? How satisfied are you with the consistency of the organization's pay policies?). The Cronbach $\alpha$ estimates of internal consistency for Pay Level, Pay Raise, Benefits, and Pay Administration were .91, .87, .80, and .89, respectively.

The General Satisfaction construct of the Job Diagnostic Survey (Hackman \& Oldham, 1975) was used to measure job satisfaction. It is an overall measure of the employee's satisfaction and happiness in his or her work. They were five statements (e.g Generally speaking, I am very satisfied with this job. I am generally satisfied with the kind of work I do in this job.) The Cronbach $\alpha$ estimates of internal consistency for job satisfaction were.72.

\section{Results}

To analyze the nature of the relationships between pay satisfaction and its dimensions of pay level, benefits, pay raises and administration/structure with job satisfaction we use the Chi Square Independence Test. In order to establish a relationship between the variables at a 95\% confidence interval we need to have a Pearson Chi Square coefficient at less than .05. Table 1 shows the results of the test for pay level and job satisfaction. The Chi Square coefficient, expressed through Asymp.Sig. (2-sided), $=0.048$ which is less than $p=0.05(5 \%)$. This shows that our variables are connected and that pay level affects job satisfaction. 
Table 1. Chi Square test between pay level and job satisfaction.

\begin{tabular}{|c|c|c|c|}
\hline \multicolumn{4}{|l|}{ Chi-Square Tests } \\
\hline & Value & $d f$ & $\begin{array}{l}\text { Asymptotic } \\
\text { Significance } \\
\text { (2-sided) }\end{array}$ \\
\hline Pearson Chi-Square & $7.901^{a}$ & 3 & 0.048 \\
\hline Likelihood Ratio & 11.758 & 3 & 0.008 \\
\hline $\begin{array}{l}\text { Linear-by-Linear } \\
\text { Association }\end{array}$ & 4.646 & 1 & 0.031 \\
\hline$N$ of Valid Cases & 200 & & \\
\hline
\end{tabular}

Table 2 shows the results of the test for benefits and job satisfaction. The Chi Square coefficient, expressed through Asymp.Sig. (2-sided), $=0.254$ which is greater than $p=$ $0.05(5 \%)$. This shows that these two variables are independent of each other and that benefits do not affect job satisfaction.

Table 2 Chi Square test between benefits and job satisfaction.

\begin{tabular}{|l|l|l|l|}
\hline \multicolumn{2}{|l|}{ Chi-Square Tests } & & $\begin{array}{l}\text { Asymptotic } \\
\text { Significance } \\
\text { (2-sided) }\end{array}$ \\
\hline & Value & $d f$ & 0.254 \\
\hline Pearson Chi-Square & $4.071^{a}$ & 3 & 0.269 \\
\hline Likelihood Ratio & 3.935 & 3 & 0.193 \\
\hline $\begin{array}{l}\text { Linear-by-Linear } \\
\text { Association }\end{array}$ & 1.693 & 1 & \\
\hline N of Valid Cases & 200 & & \\
\hline
\end{tabular}

Table 3 shows the results of the test for pay raises and job satisfaction. The Chi Square coefficient, expressed through Asymp.Sig. (2-sided), has a value $=0.075>0.05$, thus showing that even pay raises are not related with job satisfaction.

Table 3. Chi Square test between job satisfaction and pay raise.

\begin{tabular}{|c|c|c|c|}
\hline \multicolumn{4}{|l|}{ Chi-Square Tests } \\
\hline & Value & $d f$ & $\begin{array}{l}\text { Asymptotic } \\
\text { Significance } \\
\text { (2-sided) }\end{array}$ \\
\hline Pearson Chi-Square & $6.918^{a}$ & 3 & 0.075 \\
\hline Likelihood Ratio & 7.076 & 3 & 0.070 \\
\hline $\begin{array}{l}\text { Linear-by-Linear } \\
\text { Association }\end{array}$ & 1.759 & 1 & 0.185 \\
\hline$N$ of Valid Cases & 200 & & \\
\hline
\end{tabular}

Table 4 shows the data from the independence test of administration/structure and job satisfaction. The results reflect a lack of relationship between the 
administration/structure dimension and job satisfaction as the value of the Pearson Chi coefficient in this case is $0.336>0.05$.

Table 4 Chi Square test between job satisfaction and organizational structures.

\begin{tabular}{|l|l|l|l|}
\hline \multicolumn{2}{|l|}{ Chi-Square Tests } & & $\begin{array}{l}\text { Asymptotic } \\
\text { Significance } \\
\text { (2-sided) }\end{array}$ \\
\hline & Value & $d f$ & 0.336 \\
\hline Pearson Chi-Square & $3.382^{a}$ & 3 & 0.328 \\
\hline Likelihood Ratio & 3.446 & 3 & 0.086 \\
\hline $\begin{array}{l}\text { Linear-by-Linear } \\
\text { Association }\end{array}$ & 2.943 & 1 & \\
\hline N of Valid Cases & 200 & & \\
\hline
\end{tabular}

To explore the relationship between overall pay satisfaction and job satisfaction we construct a multiple linear regression, as follows:

$Y_{i}=b_{0}+b_{1} X_{1}+b_{2} X_{2}+\ldots . . b_{n} X_{n}+\varepsilon_{i}$.

First we see the multicollinearity of the independent variables between them (in our case 4 dimensions of pay satisfaction). The values of the following data show that the coefficient of their interaction is within the allowed limits -0.7 to 0.7 , thus the correlation between them does not pose a problem in their interaction with job satisfaction as the dependent variable (Table 5).

Table 5 Correlation between pay satisfaction dimensions.

\begin{tabular}{|l|l|l|l|l|l|}
\hline \multicolumn{2}{|l|}{} & $\begin{array}{l}\text { Pay } \\
\text { Level }\end{array}$ & Benefits & $\begin{array}{l}\text { Pay } \\
\text { Raise }\end{array}$ & Administration/Structure \\
\hline Pay Level & $\begin{array}{l}\text { Pearson } \\
\text { Correlation }\end{array}$ & 1 & $.632^{* *}$ & & \\
\hline Benefits & $\begin{array}{l}\text { Pearson } \\
\text { Correlation }\end{array}$ & $.632^{* *}$ & 1 & & \\
\hline Pay Raise & $\begin{array}{l}\text { Pearson } \\
\text { Correlation }\end{array}$ & $.624^{* *}$ & $.643^{* *}$ & 1 & \\
\hline Administration/Structure & $\begin{array}{l}\text { Pearson } \\
\text { Correlation }\end{array}$ & $.641^{* *}$ & $.680^{* *}$ & $.683^{* *}$ & 1 \\
\hline
\end{tabular}

\section{**. Correlation is significant at the 0.01 level (2-tailed).}

Before constructing the regression equation we refer to the ANOVA analysis. Table 6 shows that there is a relationship between the dimensions of pay satisfaction and job satisfaction since the value of Sig. $=0.00<0.05$. 


\section{Table 6. ANOVA}

\begin{tabular}{|c|c|c|c|c|c|c|}
\hline \multicolumn{7}{|c|}{ ANOVAa } \\
\hline \multicolumn{2}{|c|}{ Model } & $\begin{array}{l}\text { Sum of } \\
\text { Squares }\end{array}$ & $d f$ & $\begin{array}{l}\text { Mean } \\
\text { Square }\end{array}$ & $F$ & Sig. \\
\hline \multirow[t]{3}{*}{1} & Regression & 4.517 & 4 & 1.129 & 5.374 & $.000 \mathrm{~b}$ \\
\hline & Residual & 40.983 & 195 & 0.210 & & \\
\hline & Total & 45.500 & 199 & & & \\
\hline
\end{tabular}

a. Dependent Variable: job satisfaction

b. Predictors: (Constant), Organizational structure, Benefits, pages Page increase, Level of Payment

Data in table 7 shows that in this correlation two dimensions of pay satisfaction are directly related to job satisfaction. They are pay level and pay raises as the respective values of Sig. are .005 and 0.00 , both $<0.05$.

Therefore our equation will have the form:

(Job satisfaction) $=3.127+0.117$ (Pay Level) +0.047 (Raises)

Table 7 Multiple regression analysis between pay dimensions and job satisfaction.

\begin{tabular}{|l|l|l|l|l|}
\hline Model & $R^{2}$ & $R^{2}$ adjusted & $t$ & Sig. \\
\hline Constant & & & & \\
\hline Pay Level & 0.399 & 0.381 & & \\
\hline Benefits & & & 19.693 & 0.000 \\
\hline Pay Raise & & & 1.947 & 0.053 \\
\hline Administration/Structure & & & -4.027 & $\mathbf{0 . 0 0 0}$ \\
\hline
\end{tabular}

Pay level has a greater influence on job satisfaction than pay raises as shown by the higher coefficient $\beta=0.117$.

\section{Discussions and Conclusions}

The study discovered that not all dimensions of pay satisfaction were related with job satisfaction. Overall pay satisfaction and pay level were related to job satisfaction while pay raises, benefits and administration/structure were not. The relationships of pay and pay level satisfaction with job satisfaction were expected considering empirical studies and the lack of relationships for the other three dimensions can be explained with the context in which the study was conducted. Organizations in the public sector might offer benefits of lesser value and number because of budgetary constraints. Employees in Albania also value much more the direct cash rewards like salaries or bonuses than indirect non cash rewards like benefits. Pay raises in the 
public sector are not frequent and usually just adjust the salaries to the level of inflation. The public sector causes limitations for the study. It is recommendable to also conduct this study on private sector employees in order to fully explore the nature of the relationships.

\section{References}

[1] Ago, A., C. Mueller and J. Price. 1993. "Determinants of Job Satisfaction: An Empirical Test of a Causal Model." Human Relations, 46, 1007-1027.

[2] Best, M.F., and N.E. Thurston. 2006. "Canadian Public Health Nurses' Job Satisfaction." Public Health Nursing, 23 (3), 250-255.

[3] Carraher, S. M., \& Buckley, M. R. (1996). Cognitive complexity and the perceived dimensionality of pay satisfaction. Journal of Applied Psychology, 81, 102-109.

[4] Currall S.C., Towler A.J., Judge T.A., Kohn L. (2005). Pay satisfaction and organizational outcomes. Personnel Psychology 58, 613-640

[5] DeConinck, J. B., Stilwell, C. D., \& Brock, B. A. (1996). A construct validity analysis of scores on measures of distributive justice and pay satisfaction. Educational and Psychological Measurement, 56, 1026-1036

[6] Ducharme, M. J., Singh, P., \& Podolsky, M. (2005).Exploring the links between performance appraisals and pay satisfaction. Compensation and Benefits Review, 46-52.

[7] Fong, S. C. L., \& Shaffer, M. A. (2003). The dimensionality and determinants of pay satisfaction: A cross-cultural investigation of a group incentive plan. International Journal of Human Resource Management, 14, 559-580.

[8] Hackman, J.R., \& Oldham, G.R. (1975). Development of the Job Diagnostic Survey.

[9] Journal of Applied Psychology, 60, 159-170.

[10] Heneman, H.G., and D.P. Schwab. 1985. Pay Satisfaction: Its Multidimensional Nature and Measurement. International Journal of Psychology, 20, 129-141.

[11] Heneman, R. L., Greenberger, D. B., \& Strasser, S. (1988). The relationship between pay-for-performance perceptions and pay satisfaction. Personnel Psychology, 41, 745-761.

[12] Hulin, C. L. (1991). Adaptation, persistence, and commitment in organizations. In M. D. Dunnette \& L.M. Hough (Eds.), Handbook of industrial and organizational psychology, Vol. 2. (pp. 445-505)Palo Alto, CA: Consulting Psychologists Press.

[13] Kinicki, A.J., McKee-Ryan, F.M., Schriescheim, C.A. and Carson, K.P. (2002), "Assessing the construct validity of the job descriptive index: a review and meta-analysis", Journal of Applied Psychology, Vol. 87, pp. 14-32.

[14] Koh, H.C. and Boo, H.Y. (2001), "The link between organizational ethics and job satisfaction: a

[15] study of managers in Singapore", Journal of Business Ethics, Vol. 29, pp. 30924. 
[16] Judge, T.A., 1993. Validity of the dimensions of the pay satisfaction questionnaire: evidence of differential prediction. Personnel Psychology. 46, 331-355.

[17] Locke, E.A. (1976), "The nature and causes of job satisfaction", in Dunnette, M.D. (Ed.), Handbook of Industrial and Organizational Psychology (pp. 1297343), Rand McNally: Chicago, IL.

[18] Miceli, M. P., \& Lane, M. C. (1991). Antecedents of pay satisfaction: A review and extension. In K. Rowland \& J. Ferris (Eds.), Research in personnel and human resources management (Vol. 9, pp. 235-309). Greenwich, CT: JAI Press.

[19] Orpen, C., \& Bonnici, J. (1987).A factor analytic investigation of the Pay Satisfaction Questionnaire. The Journal of Social Psychology, 127, 391-392

[20] Ram, P., \& Prabhakar, G. V. (2010). Determinants of pay satisfaction: A study of the hotel industry in Jordan. European Journal of Social Sciences, 14, 442454.

[21] Scarpello, V., Huber, V., Vandenberg, R.J., 1988. Compensation satisfaction its measurement and dimensionality. Journal of Applied Psychology. 73 (2), 163171.

[22] Singh, P., Loncar N. (2010). La satisfaction à l'égard de la rémunération, la satisfaction au travail et l'intention de quitter. Relations industrielles, 65(3).

[23] Shaw, J. D., Duffy, M. K., Jenkins G. D., \& Gupta, N. (1999). Positive and negative affect, signal sensitivity, and pay satisfaction. Journal of Management, 25, 189-206.

[24] Smith, P. C., Kendall, L. M., \& Hulin, C. L. (1969). The measurement of satisfaction in work and retirement. Chicago: Rand McNally.

[25] Tremblay, M., B. Sire and D. Balkin. 2000. "The Role of Organizational Justice in Pay and Employee Benefit Satisfaction, and its Effects on Work Attitudes." Group and Organization Management, 25 (3), 269-290.

[26] Vandenberghe C, Tremblay M (2008). The Role of Pay Satisfaction and Organizational Commitment in Turnover Intentions: A Two-Sample Study . Springer Science+Business, 22, 275-286

[27] Williams, M. L, McDaniel, M. A, Nguyen, T. N. (2006). A Meta-Analysis of the Antecedents and Consequences of Pay Level Satisfaction. Journal of Applied Psychology , 91(2), 392-413 